УДК 378.016:81’243

DOI:

Лариса Довгань, кандидат педагогічних наук, доцент, дочент кафедри іноземної філологї та перекладу Віннииького торговельно-економічного інституту КНТЕУ

\title{
“ПЕРЕВЕРНУТЕ НАВЧАННЯ" ЯК СТУДЕНТОЦЕНТРОВАНИЙ ПІДХІД ДО ВИКЛАДАННЯ ІНОЗЕМНИХ МОВ
}

У статті досліджено методику “перевернутого навчання” як структурного елементу студентоцентрованого підходу до викладання іноземних мов у закладах вищої освіти. Визначено характерні особливості означеної методики навчання. Окреслено переваги та обмеження застосування методики “перевернутого навчання”. Проаналізовано сприйняття та готовність до застосування методики "перевернутого навчання" при викладанні іноземних мов у закладах вищої освіти. Зазначено, щзо застосування методики “перевернутого навчання” сприяє індивідуалізації та активізації процесу навчання, стимулює розвитоку здобувачів вищої освіти вмінь самостійної роботи та формує у них відповідальне ставлення до навчання.

Ключові слова: методика; “перевернуте навчання”; змішане навчання; студентоцентризм; вивчення іноземних мов.

תim. 8.

Larysa Dovhan, Ph.D.(Pedagogy), Associate Professor, Associate Professor of the

Foreign Philology and Translation Department of Vinnytsia Institute of Trade and Economics of KNUTE

\section{"FLIPPED LEARNING" AS A STUDENT-CENTERED APPROACH TO TEACHING FOREIGN LANGUAGES}

The article examines theoretical foundations and features of the practical application of the technology of "flipped learning" when teaching foreign languages to the students of higher educational institutions in the framework of a student-centered approach to the organization of the educational process. It is established that "flipped learning" is a student-centered teaching method, according to which the students acquire fundamental educational information before the classed and during the classes they gain experience of learning foreign languages in the interaction with each other and with the teacher. The main idea of the method of "flipped learning" is based on the idea that training of students should take place both in the classroom and individually within extracurricular activities using a set of innovative teaching apps, modern information and communication technologies. It is established that the purpose of "flipped learning" is to use the technology to increase opportunities for interaction between the students and the teacher. It is determined that one of the preconditions for applying the technology of "flipped learning" when teaching foreign languages is the use of adequate audio and video equipment, software, and wide access to the Internet. Lack of appropriate hardware and software or limited access to the Internet significantly complicates the possibilities and reduces the effectiveness of the application of the method of "flipped learning". It is noted that application of the method of "flipped learning" when teaching foreign languages promotes individualization and activation of the learning process, stimulates the development of students 'skills of independent work and forms a responsible attitude to learning. "Flipped learning" also facilitates individualization of the learning process and allows the student to control its time and intensity.

Keywords: method, "flipped learning"; blended learning; student-centered approach; learning foreign languages.

$\Pi$

остановка проблеми. Сучасні виклики, які постають перед системою вищої освіти в XXI ст., потребують перегляду традиційних підходів до змісту та наповнення освітнього процесу. Глобалізація й інтеграція світового економічного, політичного та культурного просторів вимагає формування у майбутніх фахівців професійних іншомовних компетенцій, необхідних для налагодження взаємодії у просторі світової та європейської комунікації.

Підготовка кадрів, які здатні до творчого розв’язання професійних задач та готові до неперервної освіти і саморозвитку в динамічно мінливих умовах зовнішнього середовища, ускладнюється проблемами, пов'язаними із слабкою навчально-пізнавальною мотивацією та відповідальністю здобувачів, відсутністю бажання навчатись і вмінь самостійно працювати, недостатністю аудиторного часу для застосування педагогами індивідуального підходу і для закріплення одержаних здобувачами знань та відпрацювання набутих компетенцій тощо.

За таких умов актуальності набуває пошук 
нових ефективних напрямів взаємодії у системі “викладач-здобувач”, які можуть знайти застосування в рамках сучасного студентоцентрованого підходу до організації освітнього процесу вищої школи. Одним із таких напрямів при викладанні іноземних мов здобувачам вищої освіти може стати застосування інноваційної педагогічної методики -“перевернуте навчання” (англ. Flipping Learning).

Аналіз останніх досліджень і публікацій. Питанням впровадження студентоцентрованого підходу в вищій освіті присвячені праці таких вітчизняних та зарубіжних науковців, як В. Андрющенко, В. Віттерн, В.Кремень,А. Мельниченко, Дж. Равен, Ю . Рашкевич, Р. Флюеллінг, О. Шаров, А. Шудло, та ін.

Теоретичні засади та особливості практичного застосування методики "перевернутого навчання" висвітлені в працях С. Бейкера, Дж. Бергмана, Д. Беррета, М. Гормана, Г. Гріна, Т. Дрісколла, Г. Маршала А. Самса та інших вітчизняних i зарубіжних учених. Оскільки цей підхід є новим для вищої школи України, то його грунтовне вивчення і розробка рекомендацій щодо його впровадження в освітній процес 3 ВО є актуальним та вагомим завдання сьогодення.

Незважаючи на вагомість наукового доробку щодо означеної проблематики, нерозв'язаними залишаються питання наукового обгрунтування застосування методики “перевернутого навчання" здобувачів вищої освіти при вивченні іноземних мов. Це питання $є$ актуальним, маловивченим, потребує уваги науковців, що і обумовило мету та завдання пропонованої статті.

Метою статті $\epsilon$ висвітлення теоретичних засад та особливостей практичного застосування технології “перевернутого навчання” при викладанні іноземних мов здобувачам закладів вищої освіти в рамках студентоцентрованого підходу до організації освітнього процесу.

Виклад основного матеріалу дослідження. Необхідність запровадження дистанційного навчання, зумовленого всесвітньої пандемією, спонукає педагогів до активного пошуку інноваційних форм і методів навчання, які були б ефективними саме у системі он-лайн освіти та забезпечували належну підготовку майбутніх фахівців. Якісна організація освітнього процесу в умовах карантину також вимагає оновлення методичного забезпечення відповідно до сучасних викликів та стандартів освіти.

Сучасні тенденції організації навчального процесу у закладах вищої освіти свідчать про безперервну розробку та удосконалення стратегій, які б забезпечували якісне засвоєння навчального матеріалу та формування базових професійних компетентностей і програмних результатів навчання.

На сьогодні, у вітчизняній та зарубіжній системі освіти впроваджується доволі широкий діапазон інноваційних та експериментальних педагогічних технологій, які передбачають активне залучення мережі Інтернет, створення й поширення власного контенту, можливість самоудосконалюватися шляхом участі в онлайнконференціях, форумах, вебінарах та семінарах тощо.

В умовах онлайн навчання значний інтерес становить методика “переверненого навчання", яка набуває актуальності і активного застосування як у зарубіжній, так і у вітчизняній педагогічній практиці завдяки акценту на самостійну роботу студента, якісне методичне забезпечення i активізацію його пізнавальної активності.

В освітніх програмах вищих закладів освіти особливу увагу зосереджено на підвищенні інтересу студентів до самостійного навчання та здатності до щоденного навчання [3].

У сучасному глобальному світі інтенсифікується розвиток економічних та пов'язаних з ними наукових взаємовідносин, а тому для забезпечення ефективної комунікаційної взаємодії зростає важливість знання майбутніми фахівцями іноземних мов.

Відповідно до нового Порядку денного Європейського союзу стосовно вищої освіти, стандартів і рекомендацій щодо забезпечення якості, у Європейському просторі вищої освіти важливим фактором формування майбутніх лідерів для успішних і конкурентоспроможних громад, професійних спільнот, держав є студентоцентрований підхід до навчання. Завданням впровадження студентоцентрованого навчання визначається надання кожному здобувачеві освіти можливостей для найбільш ефективної адаптації до сучасної динамічно мінливої реальності.

Удосконалення освітньої діяльності у сфері вищої освіти України передбачає впровадження студентоцентрованого навчання, яке визначається як підхід до організації освітнього процесу, що передбачає [2]:

1. Заохочення здобувачів вищої освіти до ролі автономних і відповідальних суб' єктів освітнього процесу.

2. Створення освітнього середовища, орієнтованого на задоволення потреб та інтересів здобувачів вищої освіти, зокрема надання можливостей для формування індивідуальної освітньої траєкторії.

3. Побудову освітнього процесу на засадах 


\section{“ПЕРЕВЕРНУТЕ НАВЧАННЯ" ЯКСТУДЕНТОЦЕНТРОВАНИЙПДХІД ДОВИКЛАДАННЯ ІНОЗЕМНИХ МОВ}

взаємної поваги і партнерства між учасниками освітнього процесу.

Упровадження студентоцентрованого підходу та зміна системоцентричної лінгвістичної парадигми на антропоцентричну сприяли формуванню комунікативного підходу до навчання мови, який розглядає мову як “систему вираження значень”, первинною функцією якої $є$ комунікативна взаємодія $[8,71]$. У рамках цього студентоцентрованого підходу здобувачі вищої освіти мають стати активними учасниками процесу навчання, а викладач має володіти компетенціями для здійснення ефективної координації такої комунікації.

Основні способи активізації навчальнопізнавальної діяльності здобувачів при вивченні іноземних мов висвітлені в працях ряду дослідників $[1 ; 6 ; 7]$. Відповідно до результатів проведених досліджень, підвищення активності здобувачів може бути досягнуто завдяки застосуванню таких інноваційних видів навчання, як змішане, дистанційне, електронне, інтерактивне тощо. Інтенсивний розвиток інформаційнокомунікаційних технологій та їх широке впровадження в освітній процес дозволили якісно удосконалити ідею попереднього самостійного вивчення здобувачами навчального матеріалу, що сприяє поширенню такої інноваційної методики змішаного навчання, як “перевернутий клас" або “перевернуте навчання".

"Перевернутий клас" є студентоцентрованою методикою навчання, при застосуванні якої здобувачі вивчають основну навчальну інформацію перед аудиторним заняттям, а в аудиторії отримають активний досвід вивчення іноземної мови у взаємодії між собою та 3 викладачем.

Метою "перевернутого навчання" $\epsilon$ використання означеної технології для збільшення можливостей взаємодії вчитель-студент та студент-студент шляхом зміни динаміки подання інформації [4].

Перші згадки про практичне застосування методики “перевернутого навчання" з'являються в США (2007), хоча теоретичні передумови для розробки навчальної методики формувались в кінці 1990-х рр., а терміни “перевернутий клас" і “перевернуте навчання" згадувались в педагогічній літературі на їх початку. Засновниками методики "перевернутого класу" прийнято вважати двох шкільних учителів хімії Дж. Бергмана та А. Самса. Вони запропонували учням, які пропустили заняття, засвоїти пропущений навчальний матеріал не на додаткових заняттях, а за допомогою спеціально створених вчителями відеолекцій. Згодом Дж. Бергман та А. Самс запропонували учням переглядати відеолекції перед заняттями, а на заняттях зосередитись на виконанні практичних завдань та вправ, що стало основою інноваційної педагогічної методики, яка отримала назву “перевернутий клас".

На нашу думку, технологія "перевернутого навчання" може успішно застосовуватися під час вивчення іноземних мов в умовах змішаного навчання. Особливої актуальності застосування методики "перевернутого класу" при вивченні іноземних мов здобувачами вищої освіти немовних спеціальностей набуває у сучасній українській вищій школі. В умовах скорочення аудиторного часу, відведеного на вивчення іноземних мов, відмови від проведення аудиторних занять 3 іноземної мови в лабораторному режимі, збільшення чисельності здобувачів в академічних групах викладачам іноземних мов стає дедалі складніше досягати запланованих програмних результатів навчання, формувати у здобувачів необхідні загальні та професійні компетентності.

Перенесення початкових етапів вивчення навчальних матеріалів 3 іноземної мови на самостійне опрацювання дає змогу звільнити обмежений аудиторний час від здійснення пізнавальних дій низького рівня та можливості його використання для здійснення когнітивної комунікаційної діяльності більш високого рівня. Тобто процес запам'ятовування навчальної інформації може бути перенесено 3 аудиторії у сферу попереднього самостійного вивчення, що цілком відповідає студентоцентрованому підходу та заохочує здобувачів вищої освіти до ролі автономних і відповідальних суб' єктів освітнього процесу.

Таким чином, процес аудиторного вивчення іноземної мови буде полягати в продуктивних діях викладачів для формування у здобувачів розуміння навчальної інформації, відпрацювання компетенцій для ії застосування, аналізу, синтезу та оцінки.

Студентоцентрованість при застосуванні методики “перевернутого навчання” досягається завдяки активізації процесу навчання, розвитку у здобувачів вмінь самостійного навчання та формування відповідального ставлення до навчання. "Перевернуте навчання" також дає змогу полегшити індивідуалізацію процесу навчання та надати можливість здобувачу самостійно контролювати час та темп навчання при вивченні іноземної мови.

У педагогічній науковій літературі представлено велику кількість моделей 
застосування методики “перевернутого навчання". Кожен викладач іноземної мови самостійно може обрати прийнятний для себе варіант “перевернутого класу”, однак обов'язковою умовою $є$ застосування комплексу засобів цієї методики, а не окремих його елементів. Тільки в такому випадку застосування методики "перевернутого навчання" буде ефективним.

Однією із передумов для застосування методики “перевернутого навчання" при викладанні іноземних мов $є$ якісне забезпечення комп'ютерною, аудіо- та відеотехнікою, програмне забезпечення, а також широкий доступ до мережі Інтернет. Відсутність у викладача або у здобувачів належного техніко-програмного забезпечення або обмеженість доступу до мережі Інтернет суттєво ускладнює можливості та знижує результативність застосування методики “перевернутого навчання".

Відповідно до результатів дослідження ступеня сприйняття здобувачами вищої освіти впровадження методики “перевернутого навчання", які висвітлені в роботі [5], близько 85 $\%$ респондентів прихильно сприймають ідею інтеграції моделі “перевернутий клас" в навчальний процес, а 75 \% респондентів позитивно оцінюють можливості для співпраці та комунікації в середовищі електронного навчання.

Висновки. Методика “перевернутого навчання" є одним із сучасних педагогічних методів студентоцентрованого підходу до навчання та організації освітнього процесу у закладах вищої освіти. Основна ідея методики “перевернутого навчання” полягає у тому, що навчання здобувачів вищої освіти повинно проходити як в аудиторії, так і за іiі межами, за допомогою комплексу інноваційних засобів навчання та 3 використанням сучасних інформаційно-комунікаційних, технікотехнологічних, освітніх і педагогічних рішень. Застосування методики “перевернутого навчання" при вивченні іноземних мов сприяє індивідуалізації, персоналізації і активізації процесу навчання, стимулює розвиток у здобувачів вищої освіти вмінь самостійної роботи та формує у них відповідальне ставлення до навчання.

Подальших наукових досліджень потребує проблематика подолання обмежень до впровадження та застосування інноваційних методик викладання іноземних мов у закладах вищої освіти.

\section{ЛІТЕРАТУРА}

1. Довгань Л. Система неформальної освіти дорослих у сільській місцевості. Молодь і ринок. 2020. № 1 (180). C. 108-113. DOI: https://doi.org/ 10.24919/2308-4634.2019.166285

2. Про внесення змін до деяких законів України щодо вдосконалення освітньої діяльності у сфері вищої освіти: Закон України від 18 грудня 2019 р. № 392-IX. URL: https://zakon.rada.gov.ua/laws/ show/392-20\#Text (дата звернення: 15.05.2021).

3. Bergmann J. \& Sams A. (2012). Flip your classroom: reach every student in every class every day. Eugene, Or. : Alexandria, Va.: International Society for Technology in Education.

4. Egbert J., Herman D. \& Lee H.: Flipped instruction in English language teacher education: a design-based study in a complex, open-ended learning environment. Teach. Engl. Second Foreign Lang. 2015. Vol. 19 (2). pp. 1-23.

5. Evseeva A. \& Solozhenko A. Use of flipped classroom technology in language learning. Procedia - Soc. Behav. Sci. 2015. Vol. 206. pp. 205-209.

6. Havryliuk N., Osaulchyk O., Dovhan L. \& Bondar N. Implementation of e-learning as Society. Integration. Education. Proceedings of the International Scientific Conference. 2020. Vol. IV. pp. 449-459. DOI: https://doi.org/10.17770/ sie2020vol4.5019.

7. Ivanytska N., Tymoshchuk N., Dovhan L., Osaulchyk O. \& Havryliuk N. Effectiveness of digital resources in the learning management system within online education of future entrepreneurs. Journal of Entrepreneurship Education. 2021. Vol. 24 (4). pp. 1-8.

8. Richards J. C. \& Rodgers T. S. Approaches and Methods in Language Teaching. Cambridge : Cambridge University Press, 1986.

\section{REFERENCES}

1. Dovhan, L. (2020). Systema neformalnoi osvity doroslykh u silskii mistsevosti [Non-formal adult education system in rural areas]. Youth and market. No. 1 (180). pp. 108-113. DOI: https://doi.org/ 10.24919/2308-4634.2019.166285 [in Ukrainian].

2. Pro vnesennia zmin do deiakykh zakoniv Ukrainy shchodo vdoskonalennia osvitnoi diialnosti u sferi vyshchoi osvity [On amendments to some laws of Ukraine on the improvement of educational activities in the field of higher education]. Law of the Ukraine (2019). No. 392-IX. Available at: https:// zakon.rada.gov.ua/laws/show/392-20\#Text. (Accessed 15 May 2021). [in Ukrainian].

3. Bergmann, J. \& Sams, A. (2012). Flip your classroom: reach every student in every class every day. Eugene, Or. : Alexandria, Va.: International Society for Technology in Education. [in English].

4. Egbert, J., Herman, D. \& Lee, H. (2015). Flipped instruction in English language teacher 


\section{ПРАКТИЧНЕ ЗАСТОСУВАННЯ МОДЕЛІ ІНТЕГРОВАНОГОНАВЧАННЯ ШКОЛЯРІВ НА ПРИКЛАДІ ВИВЧЕННЯ ФОРТЕПІАННИХ ТВОРІВ УКРАЇНСЬКИХ КОМПОЗИТОРІВ}

education: a design-based study in a complex, openended learning environment. Teach. Engl. Second Foreign Lang. Vol. 19 (2). pp. 1-23. [in English].

5. Evseeva, A. \& Solozhenko, A. (2015). Use of flipped classroom technology in language learning. Procedia - Soc. Behav. Sci. Vol. 206, pp. 205-209. [in English].

6. Havryliuk, N., Osaulchyk, O., Dovhan, L. \& Bondar, N. (2020). Implementation of e-learning as Society. Integration. Education. Proceedings of the International Scientific Conference. Vol. IV. pp. 449-
459. DOI: https://doi.org/10.17770/sie2020vol4.5019. [in English].

7. Ivanytska, N., Tymoshchuk, N., Dovhan, L., Osaulchyk, O. \& Havryliuk, N. (2021). Effectiveness of digital resources in the learning management system within online education of future entrepreneurs. Journal of Entrepreneurship Education. Vol. 24 (4). pp. 1-8. [in English].

8. Richards, J. C. \& Rodgers, T. S. (1986). Approaches and Methods in Language Teaching. Cambridge : Cambridge University Press, [in English].

Стаття надійшла до редакції 19.04.2021

УДК 37.02: 780.616.432-053.2./5[37.015.31:78] (477)

DOI:

Ірина Новосядла, кандидат мистеитввознавства, дочент кафедри методики музичного виховання та диригування ДВНЗ “Прикарпатський національний університет імені Василя Стефаника"

Тетяна Гуцол, магістрантка навчально-наукового інституту мистецтв ДВНЗ “Прикарпатський наџіональний університет імені Василя Стефаника"

\section{ПРАКТИЧНЕ ЗАСТОСУВАННЯ МОДЕЛІ ІНТЕГРОВАНОГО НАВЧАННЯ ШКОЛЯРІВ НА ПРИКЛАДІ ВИВЧЕННЯ ФОРТЕПІАННИХ ТВОРІВ УКРАЇНСЬКИХ КОМПОЗИТОРІВ}

У статті розглядається поєднання зразків украӥнської музичної та літературної творчості як модель інтегративного підходу в музичному вихованні школярів з метою розвитку ї образно-асочіативного мислення. Наголошується на ефективності такого взаємозв 'язку, на величезному дидактичному потенціалі і української фортепіанної музики, і поезії як ї̈ програми, щуо сприяє активізації творчої уяви школярів і кращяому розумінню художнього змісту творів. Пропонуються варіанти прикладів фортепіанних п'єс і віршів відомих украӥнських митиів минулого, сучасних авторів для різного шкільного віку.

Ключові слова: музичне виховання; інтегративний підхід; розвиток образно-асоиіативного мислення; програмна музика; фортепіанні твори українських композиторів; українська поезія.

תim. 12.

Iryna Novosiadla, Ph.D.(Art Science), Associate Professor of the Music Education and Conducting Methods Department,

State Higher Educational Institution "Vasyl Stefanyk Precarpathian National University"

Tetiana Hutsol, Master Student of the Educational-Scientific Institute of Art, State Higher Educational Institution "Vasyl Stefanyk Precarpathian National University"

\section{THE PRACTICAL USE OF INTEGRATIVE LEARNING MODEL OF SCHOOLCHILDREN ON THE EXAMPLE OF STUDYING PIANO WORKS BY UKRAINIAN COMPOSERS}

The article considers the combination of samples of Ukrainian musical and literary creativity as an example of an integrative approach in music education of schoolchildren in order to develop their figurative and associative thinking. An attention is focused on the importance of poetry as a poetic program of piano works, on the great expressive possibilities of the synthesis of poetry and music. The strong connection between music and literature is determined by the fact that each of them affects the emotional sphere of the student, promotes the creative development of the individual.

Ukrainian piano music has a huge didactic potential for use in Arts-based learning. Its samples acquaint students with national musical traditions, represented by genre varieties of Ukrainian folklore, works of composers representing different regions of Ukraine. The combination of piano works with poems by Ukrainian poets will promote the activation of associative thinking and a better understanding of music. The choice of works should take into account the age characteristics of students, the depth of the emotional impact of the piano pieces on students, the accessibility of the content of the poems, their artistic and aesthetic value. 